\title{
Chronic Massive Fetomaternal Hemorrhage in a newborn from immigrants. Clinical and organizational implications
}

\author{
Emorragia feto-materna massiva e cronica. Implicazioni cliniche e gestionali
}

E. Ruffini, ${ }^{1}$ A. M. Bianchi, ${ }^{1}$ L. De Petris, ${ }^{1}$ M. K. Fares, ${ }^{1}$ G. Zorzi, ${ }^{1}$ A. Carlucci ${ }^{1}$

Key words: Fetomaternal hemorrhage, neonatal anemia, pregnant immigrants

\begin{abstract}
Fetomaternal hemorrhage (FMH) refers to the entry of fetal blood into the maternal bloodstream before or during delivery. FMH of more than $30 \mathrm{~mL}$ occurs with the frequency of about $1 / 300$. Fetal outcomes may be compromised by still births, hydrops fetalis, cardiac complications, and increased rates of postpartum infant death. In most cases, the cause is not identified. Clinical manifestations of FMH depend on the volume of blood lost and the rate that it occurred. We report a case of chronic massive FMH in a newborn of an immigrant mother with a favorable outcome. Medical visits and tests during pregnancy, including ultrasound scans, were not performed. The baby was hemodynamically stable after birth, manifesting only pallor. The complete blood count revealed severe hypochromic anemia (hemoglobin 3,8 $\mathrm{g} / \mathrm{dl}$, hematocrit $14,4 \%$ ) and reticulocytosis (reticulocyte 25,2\%). There was no ABO blood type incompatibility and the result of direct Coomb's test was negative. The Kleihauer-Betke test revealed $5 \%$ of fetal erythrocytes in the maternal bloodstream equivalent to $180 \mathrm{~mL}$. The fact that FMH can occur without prior risk factors, and the diagnosis is often postnatal, underscores the importance of heightened of medical suspicion particularly in infants born to immigrants where there is often the lack of prenatal visits.
\end{abstract}

1 Pediatrics and Neonatology Division, Maternal and Infant Department,

Mazzoni Hospital, Ascoli Piceno, Italy

Indirizzo per la corrispondenza (Corresponding author):

E. Ruffini

Pediatrics and Neonatology Division, Maternal and Infant Department, Mazzoni Hospital Via degli Iris, 1

63100, Ascoli Piceno

Italy

E-mail: eruffini@libero.it

\section{Riassunto}

L' Emorragia Feto materna (EFM) riguarda l'entrata del sangue fetale nel sangue materno prima o durante il parto. L' EFM superiore a $30 \mathrm{~mL}$ si verifica con la frequenza di circa $1 / 300$. Il neonato affetto puo' essere compromesso in vario modo: nato morto, idrope fetale, complicanze cardiache e aumento del tasso di mortalità infantile dopo il parto. Nella maggior parte dei casi, la causa non è identificata. Le manifestazioni cliniche della EFM dipendono dal volume di sangue perso e dal tempo in cui avviene lo scambio. Riportiamo un caso di EFM cronica massiva in un nato da madre madre immigrata con un esito favorevole. Le visite mediche e i test durante la gravidanza, tra cui l'ecografia, non sono stati effettuati. Alla nascita il bambino era emodinamicamente stabile manifestando solo pallore. L'esame emocromocitometrico eseguito ha mostrato una grave anemia ipocromica (emoglobina 3,8 g / dl, ematocrito 14,4\%) e reticolocitosi (reticolociti 25,2\%). Non c'era incompatibilità $A B O$ tra madre e neonato e il test diretto Coombs era negativo. Il Kleihauer Betke-test ha rivelato il 5\% degli eritrociti fetali nel sangue materno corrispondente a $180 \mathrm{~mL}$. Il fatto che l' EFM possa verificarsi in assenza di fattori di rischio, e che la diagnosi sia spesso post-natale, sottolinea l'importanza di aumentare il sospetto diagnostico in particolare nei bambini nati da madri immigrate che spesso non si sottopongono alle visite prenatali.

\section{Introduction}

Fetomaternal hemorrhage (FMH) refers to the entry of fetal blood into the maternal bloodstream before or during delivery. ${ }^{1}$ Most are small-volume blood transfers from fetus to mother of less than 1 $\mathrm{mL}$; conversely, massive FMH of greater than $30 \mathrm{~mL}$ occurs in only about 3 of 1000 pregnancies and often has known prior fetal manifestations, such as decreased movement, sinusoidal heart rhythms, peripartum anemia, and fetal anomalies. ${ }^{2,3}$ Most cases of FMH are 
idiopathic in origin, most often spontaneous and involve uncomplicated near term pregnancies. ${ }^{4}$ We report a case of chronic massive FMH, which was proved by Kleihaure-Betke test, in the newborn of immigrants. Some authors have reported in their diagnosis of FMH the existence of socioeconomic and racial disparity. The purpose of this study is to describe the clinical aspects of the disease but also to emphasize the problems, increasing frequent in Italy, of the lack of visits of immigrant women during pregnancy resulting in the potential delay or missed diagnosis in the newborn.

\section{Case Report}

A 23-year-old, gravida 2, para 1, albanian woman at $372 / 7$ weeks estimated gestational age delivered a 2980 -g infant via elective caesarean section for premature rupture of membranes. Tests during pregnancy, including ultrasound scans, were not been performed. Apgar scores were 7, 8 and 8 at 1,5 and 10 minutes, respectively. The baby was breathing spontaneously and alert, but extremely pale. Thirty minutes after the birth, the newborn was still pale with systolic murmur 1-2/6 a mild hypotonia and had the following vital parameters: heart rate $168 / \mathrm{min}$, respiratory rate $54 / \mathrm{min}$, normal arterial oxygen saturation and blood pressure $55 / 33 \mathrm{mmHg}$ (mean arterial pressure $42 \mathrm{mmHg}$ ). The $\mathrm{pH}$ was 7.34 with a base deficit of $4,5 \mathrm{mEq} / \mathrm{L}$. The haemoglobin was $3,8 \mathrm{~g} / \mathrm{dl}$, hematocrit of $14.4 \%$, WBCs $15200 / \mathrm{mm} 3$ and platelets $230000 / \mathrm{mm} 3$. On the peripheral smear, reticulocytes were $25,2 \%$ and erythroblasts $28 \%$. Coombs test was negative. The newborn needed fluid therapy and one packed red blood cells transfusion of $20 \mathrm{ml} / \mathrm{kg}$, which raised the hemoglobin level to $10,7 \mathrm{~g} / \mathrm{dl}$ with a hematocrit of $34,5 \%$. Hemolytic diseases and other causes of perinatal hemorrhage were excluded. The Kleihauer-Betke test revealed 5\% of fetal erythrocytes in the maternal bloodstream equivalent to $180 \mathrm{~mL}$ according to the Cunningham formula.

The newborn improved with the fluid therapy and blood transfusion and was discharged on the 12th day, when a complete blood count showed: hemoglobin $9.2 \mathrm{~g} / \mathrm{dl}$, hematocrit $27.5 \%$, reticulocytes $1.5 \%$, WBCs $10600 / \mathrm{mm} 3$, and platelets $194000 / \mathrm{mm} 3$.

Physical and neurological evaluations were normal when the infant was discharged.

The cranial ultrasound at day 1 of life showed a bulky choroid plexus on the left side. There was no evidence of periventricular leukomalacia. Follow-up scans on day 7 confirmed a grade I intraventricular haemorrhage (IVH) on the left side. On day 30, mild ventriculomegaly was noted with resolution of the IVH.

\section{Discussion}

Fetal blood likely enters the maternal bloodstream during all pregnancies, without apparent clinical significance in most cases. ${ }^{1}$ In $96 \%$ of the cases, the loss of blood is minimal, usually only less than
$0.5 \mathrm{~mL}$ and less than $15 \mathrm{~mL}$ in more than $99 \%$. FMH of a significant volume $(>30 \mathrm{~mL})$ is rare with a frequency of about $3 / 1,000$ births. ${ }^{2,3}$ Thresholds of $80 \mathrm{~mL}$ or $150 \mathrm{~mL}$ also have been proposed to define "large" or "massive" FMH with an incidence of $0.9 / 1,000$ births and $0.2 / 1,000$ births at cutoffs of more than $80 \mathrm{~mL}$ and more than $150 \mathrm{~mL}$, respectively. ${ }^{5}$ Fetal outcomes may be compromised by still births, hydrops fetalis, cardiac complications, and increased rates of postpartum infant death. ${ }^{2}$

The risk factors of FMH include antepartum fetal death, cesarean delivery, abruptio placenta, placenta previa, manual removal of the placenta, intrapartum manipulation, antepartum genital bleeding, third-trimester trauma, placental tumors and third-trimester aminocentesis. ${ }^{2,4}$ More than $80 \%$ of cases in which the FMH was estimated to be greater than $30 \mathrm{~mL}$ remain unexplained. ${ }^{4}$

The clinical manifestations and prognosis of FMH depend on the volume of the hemorrhage and the rapidity with which it occurs. In cases of prolonged or repeated bleeding during the course of the pregnancy, anemia slowly develops, giving the fetus the possibility to develop hemodynamic compensation with increased hemopoietic activity (increased reticulocytes and erythroblasts in the peripheral smear). ${ }^{5}$ The diagnosis is often postnatal and these infants may manifest only pallor at birth. ${ }^{4}$ In acute FMH, rapid blood loss is followed by perinatal hypoxia and intrauterine death or severe anemia and hypoxia at birth. ${ }^{6} \mathrm{~A}$ decrease in fetal movements associated with abnormal cardiotocographic findings, such as a sinusoidal pattern of the fetal heart rate, traditionally equated with fetal anemia, may be a warning sign of a massive FMH, especially in a low-risk pregnancy., 5

The Kleihauer-Betke (KB) test is the standard method of detecting FMH.7 Comparison with other more expensive or technologically advanced methods such as flow cytometry has shown that the $\mathrm{KB}$ stain, like the more advanced methods, is almost equally sensitive in its detection of FMH. ${ }^{8}$

The red cell morphologic study of this infant indicated hypochromic anemia with an elevated reticulocyte count of $25,2 \%$. Compared with the value of 3-7 \% in normal newborns, this was markedly elevated. This finding suggested that the course of blood loss was a chronic process, because two to three days are usually required for a reticulocyte response to be observed, with a peak response after 10 to 14 days. ${ }^{9}$ The estimated volume of fetal blood in the maternal bloodstream was approximately $180 \mathrm{~mL}$ according to the Cunningham formula. ${ }^{10}$ Although a great amount of blood was lost, the patient only demonstrated pallor which indicated a chronic FMH with good compensation.

The short- and long-term prognosis for fetuses that experience FMH is variable. A FMH of $20 \mathrm{~mL} / \mathrm{kg}$, which represents $20 \%$ of the fetoplacental blood volume, is considered massive because it is associated with significant fetal/neonatal morbidity or mortality. ${ }^{3}$ At this cutoff, $26.1 \%$ of the fetuses were stillborn, $17.4 \%$ required preterm delivery, $34.8 \%$ were admitted to the neonatal intensive care unit, and $21.7 \%$ received postnatal transfusions. ${ }^{3}$ These risks increased with increasing fetal volume transfused. With bleeds greater than $80 \mathrm{~mL} / \mathrm{kg}$, two thirds of the fetuses died before deliv- 
ery. ${ }^{3}$ Cerebral palsy has been linked with FMH, but the likelihood of this occurring among survivors is not well defined. ${ }^{7}$

Some authors have shown that the diagnosis of FMH is associated with significant morbidity as well as regional, socioeconomic and racial disparity. ${ }^{11}$ These authors have shown that higher patient income was associated with increased likelihood of FMH diagnosis (OR 1.2), and whites were more likely to be diagnosed than ethnic minorities (OR 1.9). As the immigrant birth rate in Italy continues to rise, this becomes increasingly important. According to The National Institute for Statistics, births attributable to foreign mothers are equal to $18,8 \%$ of the total in 2010 , with peaks of $29 \%$ in some regions, compared to $6,4 \%$ in $2000 .{ }^{12}$ Of these mothers, only $4,8 \%$ have an Italian partner while the majority (14\%) have a foreign partner. ${ }^{12}$ The majority of pregnant immigrants do not perform routine obstetric visits because of religious reasons, linguistic difficulties, and their precarious socio-sanitary and economic conditions. These social and economic hardships are associated with more frequent adverse outcomes for maternal and neonatal health. In particular, there is a higher prevalence of low birth weight babies and perinatal and infant morbility. ${ }^{12}$

\section{Conclusion}

The fact that FMH can occur without prior risk factors and the diagnosis is often postnatal underscores the importance of a high index of suspicion particularly in infants born to immigrants where there is the lack of prenatal visits. The case described, first in Italy, highlights the need for particular attention by national authorities to pregnancy health care issues of immigrants.

\section{References}

1 Chown B. Anemia from bleeding of the fetus into the mother's circulation. Lancet 1954; 1: 1213-5.

2 Sebring ES, Polesky HF. Fetomaternal hemorrhage: incidence, risk factors, time of occurrence, and clinical effects. Transfusion 1990; 30:344-57.

3 Rubod C, Deruelle P, Le Goueff F, Tunez V, Fournier M, Subtil D. Longterm prognosis for infants after massive fetomaternal hemorrhage. Obstet Gynecol 2007; 110:256-60.

4 Giacoia GP. Severe fetomaternal hemorrhage: a review. Obstet Gynecol Surv 1997; 52:372-80.

5 De Almeida V, Bowman JM. Massive fetomaternal hemorrhage: Manitoba experience. Obstet Gynecol 1994; 83:323-8.

6 Thomas A, Mathew M, Unciano Moral E, Vaclavinkova V. Acute massive fetomaternal hemorrhage: case reports and review of the literature. Acta Obstet Gynecol Scand 2003; 82: 479-80.

7 Wylie BJ, D’Alton ME. Fetomaternal hemorrhage. Obstet Gynecol 2010; 115: 1039-51.

8 Katiyar R, Kriplani A, Agarwal N, Bhatla N, Kabra M. Detection of fetomaternal hemorrhage following chorionic villus sampling by Kleihauer-Betke test and rise in maternal serum alpha feto protein. Prenat Diagn 2007; 27:139-42.

9 Koepke JA. Laboratory Hematology. New York, Churchill Livingstone 1984:898.

10 Cunningham FG, MacDonald PC, Gant NF, Leveno KJ, Gilstrap LC III, Hankins GDV, et al. Williams obstetrics. 20th ed. Stamford (CT): Appleton \& Lange; 1997.

11 Stroustrup A, Trasande L. Demographics, clinical characteristics and outcomes of neonates diagnosed with fetomaternal haemorrhage. Arch Dis Child Fetal Neonatal 2011; 10: 1136.

12 The National Institute for Statistics (ISTAT). Birth and fertility rates in the resident population. 2010. 